\title{
Uraim, kérem, szabaduljanak meg tévhiteiktől!
}

\section{Szerzői információ:}

O Taká c s - Sán t a A n r ás

Ökológus, az ELTE-n végzett 1998-ban. Fô érdeklôdési területe: az ember természet-átalakító tevékenységének okai és következményei. Ebben a témában végez kutatásokat, illetve tart kötelezô és speciális kollégiumokat az ELTE Természettudományi, illetve Társadalomtudományi Karán 1999 óta. Számos tanulmánya, publicisztikája, vitacikke, hozzászólása jelent meg különbözổ lapokban. A Védegylet civil ökopolitikai szervezet alapító tagja és munkatársa.

Így hivatkozzon erre a cikkre:

Takács-Sánta András. „Uraim, kérem, szabaduljanak meg tévhiteiktől!”.

Információs Társadalom IV, 3-4. szám (2004): 69-79.

https://dx.doi.org/10.22503/inftars.IV.2004.3-4.11

A folyóiratban közölt müvek

a Creative Commons Nevezd meg! - Ne add el! - Így add tovább! 4.0

Nemzetközi Licenc feltételeinek megfelelően használhatók. 
Takács-Sánta András

Uraim, kérem, szabaduljanak meg tévhiteiktôl!

Kemény vita ez, ami Sükösd Miklós írása nyomán bontakozott ki, de vajon miért? Miért ugranak neki jó néhányan oly indulatosan Miklósnak? Vagy éppen miért olyan cinikusak egyesek? Nyilván számos oka van ennek, de véleményem szerint az egyik legfontosabb az, hogy Sükösd kritikusainak fejében (tisztelet a kivételnek!) jó pár téves, illetve elavult hiedelem él az ökológiai krízisrôl, illetve a zöldmozgalmakról (mely tévhitek amúgy nagyobbrészt sajnos közhelyek). És ami ehhez még szorosan kapcsolódik: sokszor komoly ismerethiányt mutatnak az ökológiai problémák mibenlétét, társadalmi okait és következményeiket illetôen; láthatóan nemigen ismerik az ide vonatkozó irodalmat, beleértve a tudományos szakirodalmat. (Ami bár nem örömteli, de önmagában még nem keltene visszatetszést. Csakhogy mindeközben többen is közülük Miklóst vádolják tudománytalansággal.)

Valami ilyesmit már Vay Márton is említ hozzászólásában, ő azonban inkább csak rövid utalások erejéig tér ki e hiedelmekre, illetve cáfolatukra. Magam az alábbiakban részletesebben igyekszem ezt megtenni, a leginkább szemet szúró példákat kiragadva. Mindehhez a legtöbb esetben a tudományt hívom segítségül. Ebból pedig az is következik, hogy - noha még jelen hozzászólás elött írta - nem igazán pontos Hammer Ferenc helyzetértékelése, mely szerint „....a vitában az egyik oldalon a médiakritikamozgalmárok vannak, a másik oldalon a szakma...”. Szerintem másról van itt szó. Jómagam például, noha munkálkodom egy jórészt „zöld” témákra koncentráló társadalmi szervezetben is, időm nagy részében egyetemi oktató, illetve kutató vagyok (az ELTE TTTK-n és TÁTK-n egyaránt tanítok), aki az ember természetátalakító tevékenységével, annak társadalmai okaival, illetve természeti és társadalmi következményeivel foglalkozik. Ugyanígy Lányi András (ELTE TÁTK) és Sükösd Miklós (CEU) sem vádolhatók azzal, hogy távol állna tôlük a tudomány, utóbbi ráadásul a médiaelméletnek is kiváló ismerôje. Vagyis nem szakember-laikus vita zajlik itt, hanem sokkal inkább világnézetek, értékrendek csapnak össze.

De hadd árnyaljam máris egy kicsit ezt a képet: Hammer Ferenc idézett fél= mondatával kapcsolatban gond az is, hogy azt sugallja, két jól elkülönülő oldal ütközetérôl van itt szó. Valójában Miklós kritikusai között igen nagy különbség mutatkozik a tekintetben, hogy mennyire elutasítóak a téziseivel szemben. Vagy hogy mást ne mondjak, magam ugyan nagyobb részt Miklóssal értek egyet, ám korántsem mindenben, és a mondanivalójával szemben felhozott ellenérvek egyikét-másikát meggyőzőnek, de legalábbis elgondolkodtatónak találtam.

És még valamit, mielôtt a lényegre térnénk. Ami alább következik, egyesek számára talán „offtopic”-nak tûnhet, hiszen nem közvetlenül a „mennyiben okolható a média az ökológiai válságért?” témát járja körül. Én ugyanakkor határozottan úgy gondolom, hogy csak úgy lehet igazán értelmes vitát folytatni a fenti kérdésről, amennyiben annak résztvevôi legalább az alaptényekkel tisztában vannak az ökológiai krízissel kapcsolatban. Mivel ez többek esetében nem teljesül, egy, a tévhitek eloszlatására törekvő írás igencsak relevánsnak tûnik a vitában. Lássuk is akkor az inkriminált hiedelmeket! 
1. téohit: A környezetvédelem a modern nyugati világ terméke. Ezekben az országokban ma is magas szinten van, ami egyben azt is jelenti, hogy a környezetátalakitás mértéke is alacsonyabb, mint asokban az államokban, ahol a környezetvédelem kevésbé erôteljes. Tehát e tekintetben is elórébb járnak a többieknél, ezért is tekintsük őket követendô példának.

E hiedelemcsokor (illetve egyik-másik eleme) explicit vagy implicit formában több hozzászólónál is megjelenik. Hammer Ferenc például azt írja, hogy „.... környezettudatosságot is a modernitás találta ki”. Már ez is csupán féligazság, hiszen korábban is számos - és nem csupán nyugati! - kultúrában érhetjük tetten a természeti erőforrások tudatos óvását: az erdők védelmében hozott székely falutörvényektől kezdve (Imreh, 1993) egészen az óceániai társadalmaknak a tengeri élólények megóvása érdekében foganatosított intézkedéseiig (Johannes, 1978) példák sokasága említhetô. De nem is ez a lényeg. Sokkal inkább az, hogy vajon miért is jelenik meg a környezettudatosság? Miért van szükség a környezetvédelemre? A legnagyobbnak tartott magyar ökológus, Juhász-Nagy Pál (1935-1993) bonmot-ja szerint: „....a környezetvédelem 'humán aspektusa' [n]em más, mint az embernek az emberi 'biologicum' érdekében társadalmilag szervezett önvédelme önnön maga ellen” (Juhász-Nagy, 1979). Azaz a környezetvédelem akkor hajlamos felütni a fejét, amikor környezetátalakító tevékenységünk társadalmi problémákkal, esetleg társadalmi összeomlással fenyeget. És minél nagyobbnak érzékeljük ezt a veszélyt, annál erôteljesebb környezetvédelemre van kilátás. (Természetesen a környezetvédelem erőssége további tényezőktôl is függ, de ez az egyik legfontosabb közülük, ha nem $a$ legfontosabb.)

Ráadásul a fejlett környezetvédelem sokszor csupán látszat, és nem feltétlenül jelenti a környezetátalakítás mértékének csökkenését, legalábbis ha rendszerszemléletben vizsgáljuk a dolgokat. (E látásmód hiányát kéri számon - teljes joggal - Miklós kritikusain Vay Márton.) A vita amúgy kétségtelenül egyik legszínvonalasabb írásában $Z$. Karvalics László - mint oly sokan mások is - bedől ennek a látszatnak. „'Információs korszak és természeti környezet' kontextusában a 'hogyan és miért lett Düsseldorf füstös, zajos, koszos gyáripari fellegvárból zöld mintaváros' típusú kérdéseket ugyanúgy fel lehet és fel kell tenni” - fogalmaz ô. Dessewffy Tibor pedig ezt írja: „...ld. pl. Hamburgban a korábban 200 évig mérgezett, de mára újra úszhatóvá tett Elbát, vagy Pittsburgh-ot, a hajdani acélvárost, ami ma tiszta levegôjû és élhetô". Noha az említett példákat behatóan nem ismerem, általánosságban elmondható, hogy a nyugati világban (vagy tágabban: Észak országaiban) bekövetkezô környezetjavulást nem mindig a környezetbarát technológiák (pl. a füstölgő kéményekre szerelt szûrőberendezések) terjedése eredményezi, hanem nagyon sokszor az, hogy a gazdag országok egyszerủen térben eltávolítják maguktól a környezetszennyezést, illetve a természetpusztítást a szegényebbek rovására (pl. Arrow et al., 1995). A „füstös, koszos, zajos” gyáripart áttelepítik a harmadik világba, de az általa előállított termékeket továbbra is használják; saját erdeiket védik ugyan, de a faanyag iránti igényük nem csökken (sốt, inkább növekszik), csak most éppenséggel a trópusi erdőkből elégítik ki azt. (Bizony, minden ellenkező híreszteléssel ellentétben a trópusi erdók nem elsôsorban a helyi szegények földéhsége miatt pusztulnak rohamos ütemben/persze ez is számít/, hanem a „fejlett” országok egyre fokozódó igényei következtében, ami nemcsak a faanyagra vonatkozik, hanem az erdők helyén előállított mezőgazdasági terményekre is /Meyer, 1996/.) 
A fentiek már sugallják azt az alapvetőnek tûnő - ám a hazai értelmiség körében láthatóan még meg nem emésztett - tényt, hogy Észak gazdagsága Dél kizsákmányolásán alapszik. Igen, e globális kontextusban még ma is érvényes az - általam egyébként különösebben nem kedvelt - marxizmus más tekintetben már régen elavult „kizsákányolók-kizsákmányoltak” dichotómiája: Észak polgárai, valamint Dél szûk elitje nem kis részben a világ többi lakójának kárára élvezhetik - ha élvezik egyáltalán, merthogy ez is kétséges (1. pl. Durning, 1991) - nagymértékû́ anyagi fogyasztásukat. Északnak szüksége van Dél erőforrásaira, máskülönben nem tudná fenntartani (nemhogy fokozni) ezt a fogyasztást. Jól alátámasztja mindezt például az az adat, hogy a Dessewffy Tibor által hazánk számára követendő példának tartott Hollandia ökológiai lábnyoma az ország területének legalább 15-szöröse, azaz a hollandoknak legalább 15-ször nagyobb produktív földterületre van szükségük az általuk elfogyasztott természeti erőforrások előállításához, illetve az általuk produkált szennyezések és hulladékok elnyeléséhez, mint amennyi az országhatárukon belül a rendelkezésükre áll (Wackernagel - Rees, 1996). (Nem világos ugyan, hogy Dessewffy milyen tekintetben tartja mintaértékûnek Hollandia „fejlődési pályáját”, de megfogalmazásából úgy tưnik, mintha mindenféle szempontból annak gondolná. Egyébként Magyarország ökológiai lábnyoma is messze nagyobb az ország területénél, ám jóval kisebb Hollandiáénál.)

Összefoglalásul: a világ „legfejlettebb” országai rendszerint erőteljes környezetvédelmük ellenére lényegesen nagyobb súllyal nehezednek a bioszférára, mint bármely más állam. Éppen ezért ökológiai szempontból összességében nem tekinthetjük őket mintaállamoknak.

\section{2. tévhit: Mivel a fajok kihalása természetes folyamat, a mai tömeges fajkihalások miatt sem kell aggódnunk.}

Sükösd Miklós a tudományos eredményeket korrektül tolmácsolva ezt írja: „A biológusok között konszenzus alakult ki arról, hogy fajok olyan tömeges kihalásához közelítünk, amely eddig csak öt alkalommal fordult elő a föld történetében az elmúlt 440 millió évben. A különbség az, hogy az állat- és növényfajok kipusztulásának mai, hatodik hullámát az emberi tevékenység okozza". Dessewffy Tibor reakciója erre: „Mint írod, volt már öt katasztrófa az elmúlt sok ezer évben, és most egy hatodik közeleg. [...] Ha cinikus akarnék lenni, mondhatnám, mi a probléma - ennyi, one shot jár a homo sapiensnek is..., de nem akarok cinikus lenni, csak felvetem, hogy a Föld, Gaia élőlény, változik, alakul: az emberrel és ember nélkül is eltûnnek és megjelennek fajok. Tehát, nem feltétlenül ontológiai tragédia, ha eltűnnek a bazsarózsák.” 
Dessewffynek természetesen igaza van abban, hogy Gaia folyamatosan változik, alakul, azonban egyáltalán nem mindegy a változás üteme! Tény és való, hogy fajok nélkülünk is keletkeznének és pusztulnának szüntelenül: a becslések szerint évente egy-két új fajt hoznának létre a biológiai evolúció erői, és nagyjából ugyanennyi halna ki, vagyis rövid távon dinamikus egyensúllyal számolhatnánk. Csakhogy miközben a fajok keletkezésének üteme aligha változott, a kihalásokat a „normális” érték legalább százszorosára, de valószínúbb, hogy inkább annak ezerszeresére gyorsítottuk (Pimm et al., 1995). Márpedig minél gyorsabb egy természeti változás üteme, annál nehezebben képes alkalmazkodni hozzá a társadalom.

Ám erre még mindig lehetne azt mondani - Dessewffy Tibor tulajdonképpen meg is teszi ezt -, hogy oké, oké, de hát a múltban is voltak tömeges kihalások. Vegyük azonban észre, hogy Dessewffy pontatlanul interpretálja Sükösdöt: „sok ezer év” vagy „440 millió év", korántsem mindegy! (Világos, hogy a sok ezerbe a 440 millió is belefér, mégis erôs a gyanúm, hogy D.T. nem érzi itt az idôskálák különbségét.) És hogy miért nem mindegy? A földtörténet öt nagy kihalása közül a legutolsó 65 millió éve, a kréta végén történt, ekkor pusztultak ki a dinoszauruszok is (pl. Pálfy, 1999). Hol volt ekkor az ember? Nos, sehol. Pontosabban: távoli ôseink valószínûleg apró emlősök formájában rohangáltak a dinók lábai alatt. Vagyis a mai, hatodik tömeges kihalás nem csupán az elsố olyan, amelyet az ember okoz, hanem egyben az első olyan is, amit az ember átél (bár nem biztos, hogy túl is él). Éppen ezért társadalmi szempontból édes mindegy, hogy hány nagy kihalás volt a távoli földtörténeti múltban, a jelenlegi esemény a mi nézőpontunkból precedens nélküli. (Legalábbis globális léptékben, merthogy lokálisan már soksok évvel ezelőtt is voltak ember okozta tömeges fajkihalások, például Amerika, Ausztrália, vagy számos sziget elsô kolonizációjakor/pl. Diamond, 1989/.)

De vajon miért szükséges pusztán önzố szempontok miatt is az ember számára a fajok sokfélesége? Miért probléma a fajok tömeges kihalása? Miért hiányozhat a Zengőre tervezett radarállomás által veszélyeztetett bánáti bazsarózsa és sok-sok társa? (Tudom, a lokátorépítés még nem okozná a bazsarózsa kihalását, „csak” egy nagy lépéssel közelebb vinné hozzá e veszélyeztetett alfajt.) Alapvetôen háromféle válasz kínálkozik ezekre a kérdésekre (részletesebben 1. pl. Kunin - Lawton, 1996; magyarul Ehrlich - Ehrlich, 1981, Takács-Sánta 1999).

Egyrészt az élőlények (és változatosságuk) gyönyörködtetnek bennünket. Amikor idén tavasszal forró viták zajlottak a zengôi lokátor kapcsán, a Népszabadság olvasói oldalán egy hölgy azt írta, hogy ő látta már a Mecsekben a bánáti bazsarózsát, és az egy olyan lenyűgözô szépségű növény, hogy ha a döntéshozóknak ugyanúgy lett volna szerencséjük hozzá, bizonyosan eszükbe nem jutna, hogy tönkretegyék az élőhelyét. Hasonlóképpen valószínűnek tarthatjuk, hogy Dessewffy Tibor is tragédiának tartaná a bazsarózsa eltûnését, ha személyesen ismerné, és szeretné.

Másrészt manapság számunkra feleslegesnek gondolt fajokról is könnyen kiderülhet, hogy valamiféle közvetlen materiális hasznot jelentenek az emberiségnek, például egy eddig gyógyíthatatlannak vélt emberi betegségre gyógyírt adó anyagot rejtenek testükben. Egyáltalán nem kizárt, hogy a bánáti bazsarózsáról is meg fogunk tudni valami ilyesmit. Már ha megéri.

Harmadrészt mivel Földünket az elmúlt évmilliárdok során az élőlények formálták a jelenlegi képére, és ma is nagy mértékben alakítják azt, bizonyosan nagy szerepük van abban, hogy az egyes környezeti tényezők az emberi élet számára megfelelő 
értéktartományokban vannak (pl. Vida, 2001). Nélkülük például alig volna oxigén a légkörben, és termékeny talajok sem igen lennének. Ahogy az ökológusok manapság mondani szokták: a természet technológiai úton nem, vagy csak nehezen pótolható „ingyenes szolgáltatásokat” biztosít számunkra (pl. Daily 1997, de Groot et al., 2002; magyarul Gonczlik, 2004). Noha e folyamatokból nagyon keveset értünk, annyit bizton állíthatunk, hogy az élővilág pusztítása következtében módosulhat például a légkör összetétele, avagy csökkenhet a talajok termékenysége. E változások egy bizonyos pont után az emberiség puszta létét is veszélybe sodorják, arról azonban fogalmunk sincs, hogy hol van ez a pont. Az Ehrlich házaspár híres „szegecshasonlata” szerint (Ehrlich - Ehrlich 1981) olyan ez, mintha egy repülőgépen utaznánk, és hirtelen azt vennénk észre, hogy egyik utastársunk húzogatja ki a gépbôl a szegecseket. Ráförmedünk, hogy „Ember, maga megőrült?? Le fogunk zuhanni!!” Mire ő így felel: „Nyugi, értek a repülőkhöz, és tudom, hogy néhány szegecset büntetlenül ki lehet szedni, nem fogunk emiatt lezuhanni." Mi ellenben alig-alig értünk valamit a „repülőkhöz” (azaz a bioszférához), és szinte semmit sem tudunk arról, hogy mely „szegecsek” kihúzása (azaz mely fajok kiirtása) jár majd végzetes következményekkel. A bánáti bazsarózsáé aligha, de könnyen lehet, hogy például egy teljesen haszontalannak vélt atka- vagy féregfajé pedig igen.

A fentiek alapján Dessewffy vélekedése, miszerint egy lövést mi is megérdemlünk, nem is annyira cinizmust tükröz, sokkal inkább ismerethiányt. A pisztoly csöve ugyanis végső soron a mi halántékunknál van. Az orosz rulettet pedig csak az életuntak és az idióták élvezik.

3. tévhit: A globális éghajlatváltozás nem bizonyitott tény, de még ha igaz is volna, korántsem bizonyos, hogy az ember jelentôs szerepet játszik benne.

Bár nem szó szerint ezt írja, mégis egyértelmúen e sztereotípiát olvashatjuk ki Kiss Ulrich megfogalmazásából, mely szerint „...nincs kizárva, hogy a felmelegedéselmélet csupán a nukleáris tél újabb propagandaváltozata: kell, hogy valamivel riogassák a békés polgárt”. Ha Kiss egy évtizede írja le mindezt, akkor még egy kis jóindulattal azt mondhattuk volna rá, hogy talán-talán van benne valami. Ma azonban már gyakorlatilag minden éghajlatkutató egyetért abban, hogy a klímaváltozás valós jelenség, és csekély számú kivételtôl eltekintve mindegyikük elismeri azt is, hogy elsôsorban (bár nem kizárólag) az emberi tevékenységeknek „köszönhetô”. Egyértelműen kiolvasható mindez az ENSZ égisze alatt működô, a világ vezetô éghajlatkutatóit továbbá ökológusokat, közgazdászokat, politikusokat, „zöldeket” stb. - tömörítő, a klímaváltozás témakörében szinte orákulumnak számító Éghajlatváltozási Kormányközi Testület (Intergovernmental Panel on Climate Change - IPCC) legutóbbi jelentéséből is (Watson et al., 2001). Kétségbe vonni az éghajlatváltozás tényét (vagy tagadni az ember szerepét benne) nagyjából annyit jelent, mint hülyének vagy csalónak tartani a világ legjobb klímakutatóit.

Persze lehetne itt azzal jönni - mint ahogy gyakran szoktak is -, hogy nincs százszázalékos bizonyosság a szóban forgó kérdésekben. Ez így igaz - és soha nem is lesz. Az éghajlatváltozás kapcsán a teljes bizonyosságra várni hiú remény, sőt, öngyilkossági kísérlet. A folyamatok hatalmas tér- és idôléptéke, valamint az éghajlati rendszer bonyolultsága (vö. Rind, 1999) miatt ugyanis - bármennyire is fájó - soha nem fogunk 
tudni biztosat állítani a globális klímaváltozásról. Kényszerűen csupán valószínűségekkel számolhatunk, ezek pedig azt mutatják, hogy a földi éghajlat katasztrófával fenyegetô ütemben változik, főként az emberi tevékenységeknek köszönhetően. (Ahogy már a fajok kihalása kapcsán is említettük, itt sem elsôsorban a változás mértékével van gond, hanem sokkal inkább annak az alkalmazkodást igen nehézzé tevô, földtörténeti léptékben nézve is szokatlanul és ijesztôen gyors ütemével. Megdöbbentố adat, hogy amíg a legutóbbi jégkorszak véget értekor mintegy 5000 év alatt nőtt 4 Celsius fokkal bolygónk átlaghốmérséklete, addig könnyen lehet, hogy a XXI. század során kevesebb, mint 100 év alatt fog ugyanennyivel emelkedni /Watson et al., 2001, Smil, 2002/!)

\section{4. tévhit: Vagy a fosszilis tüzelöanyagokra (kőolaj, köszén, földgáz) alapozzuk a világgaz-} daságot, vagy az atomenergiára - harmadik út nem létezik.

Ez a közkeletû́ tévhit szintúgy Kiss Ulrichnál jelenik meg a vitában, aki így fogalmaz: „Vagy vegyük a kőolaj elfogyásának elméletét (...) Nemde, logikusan az atomenergiát kellene fejleszteni?”. Nem, egyáltalán nem logikus ez. Fosszilis tüzelőanyagok vagy atomenergia? Ez olyan, mintha a halálraítélttôl azt kérdeznénk, hogy „kötelet vagy golyót parancsol"? Végül is nagyjából mindegy, nem? A fosszilisak további kiterjedt használata (jelenleg a világ energiaigényének 77\%-át elégítik ki; Sawin, 2003) az éghajlati katasztrófa rémével fenyeget, az atomenergiára való átállás pedig ugyan kis eséllyel bekövetkező, ámde akkor szintúgy katasztrofális következményekkel (pl. a csernobilihoz hasonló atomerőmü-balesetek, az erőművek ellen elkövetett terrortámadások, a föld alá elhelyezett radioaktív hulladék érintkezésbe kerülése az ivóvízkészletekkel stb.)

Szerencsére a fenti dilemma hamis, és - ahogy már Vay Márton is említi - létezik harmadik út, méghozzá az ún. megújuló energiaforrások, különösen a nap- és a szélenergia. Nyilvánvaló, hogy ezek használata sem teljesen problémamentes - az energiatermelés egyik módja sem az -, ám jóval kevesebb gondot okoznak, mint akár a fosszilis tüzelőanyagok, akár az atomenergia. Természetesen nem túnik kivitelezhetőnek, hogy a fosszilisak részesedése belátható időn belül nullára csökkenjen. Ugyanakkor reális cél, hogy egy-két évtizeden belül elveszítsék dominanciájukat, és elôtérbe kerüljenek a megújuló energiaforrások. Minden ellenkező híreszteléssel ellentétben a nap- és a szélenergia - még a technológiák jelenlegi szintjén is - önmagában is bőven ki tudná elégíteni a világ teljes energiaigényét. (Aki ezt nem hiszi, nézze meg a tényszerú, tárgyilagos elemzéseirôl ismert - vagyis elvakult környezetvédőnek nemigen nevezhető - kiváló kanadai kutató, Vaclav Smil új könyvében található alapos számításokat; Smil, 2003.) Kettejük részesedése egyébként gyors ütemben nő globálisan (Sawin, 2003; persze a nulla közeléből könnyư növekedni - mondhatnánk maliciózusan), és ebben - különösen a szélerőmúvek esetében - vezető szerepet játszik az Európai Unió némely tagországa (pl. Dánia vagy Nagy-Britannia). Magyarország sajnos nem sorolható ezen államok közé, legalábbis egyelốre, pedig hazánk adottságai viszonylag kedvezóek a szóban forgó két energiaforrás tekintetében. 


\section{5. téohit: „A környezetrombolás nagy részét nem a városi ember csinálja."}

Az idézet Hammer Ferenctôl származik, és talán a legnagyobb csacskaság, ami a vitában elhangzott. (Biztos vagyok abban, hogy szerzője sem vetette volna képernyőre, ha egy picit is végiggondolja a dolgot.)* „Az erdélyi havasok erdőit nem hiszem, hogy tévé- és/vagy internetfüggó véglények vágják ki illegálisan”- teszi hozzá H. F. És természetesen kizárólag a falusiak használják föl a faanyagot, a városi embernek semmi szüksége rá - tehetnénk hozzá hammeri gúnnyal. Sőt, természeti erőforrások sem nagyon kellenek az életéhez - nem úgy, mint a gaz, fanyưvố falusiaknak! -, a borsó például zacskóban terem az üzemben. (Nem gúnyolódnék ám Hammerral - a többi hozzászóló esetében nincsenek is ilyen szándékaim -, ha ő maga nem lett volna deklaráltan gúnyos Sükösddel szemben, és ha hozzászólásának stílusa nem lett volna számomra is bántóan nyegle és pökhendi.) A szerző mentségére legyen mondva azért, hogy nekünk, városi embereknek - sőt, a gazdasági globalizáció előrehaladtával már másokra is egyre inkább igaz mindez - rendkívül nehéz érzékelnünk az általunk elfogyasztott termékek elô- és utóéletét; rendszerint nem is rendelkezünk elegendô információval arról, hogy milyen környezetpusztításokkal jár egy-egy termék előállítása, avagy miféle gondokat okoz a belőle keletkező hulladék. Vajon például hányan gondolunk bele mindennapi csokoládénk majszolása közben, hogy az ehhez szükséges kakaóültetvények létesítése érdekében micsoda óriási területeken kellett kiirtani a trópusi erdőket?

\section{6. tévhit: $A$ „zöldek” csak tagadni tudnak, képtelenek konstruktiv alternatívákat felmutatni.}

A közhelyek közhelyét ezúttal Pintér Róbertnél olvashatjuk, szerencsére a szokottnál szelídebb formában: „Amit hiányolok nemcsak Sükösd cikkéből, hanem például az egész humánökológiai irányzatból, az az alternatívák nyújtása. A 'ne így' mellett annak megfogalmazása, hogy 'akkor hogyan'. Nem vagyok mohó, nem egy teljes rendszer leírására vágyom, ami felválthatná a mostani ördögit, beérném kevesebbel is". A vájtfüluubbek tisztán hallják a nyitott kapuk döngését, ugyanis újfent egy avítt hiedelemmel állunk szemben: Pintér állítása harminc esztendeje teljesen igaz lett volna, húsz éve is még többé-kevésbé megállta volna a helyét, egy évtizede már viszonylag nehezen lett volna védhetố, ma pedig már egyáltalán nem helyénvaló.

A szerzőt azért itt is némiképp meg kell védenünk, amennyiben igazságosak akarunk lenni vele szemben, mivel az „ökológiai alternatívák” tekintélyes nemzetközi szakirodalmából egyelôre vajmi kevés hozzáférhetô magyarul. Ám azért ez a kevés is relatív, valójában elég sok ez. A Worldwatch Institute „A világ helyzete” címen 1991 óta minden évben magyarul is megjelenő kitûnő sorozatának gyakorlatilag az összes kötetében olvashatunk a lehetséges alternatívákról. De hogy egy kicsit specifikusabbak legyünk: ami például a „másként gazdálkodás” lehetôségeit illeti, már 15 évvel ezelőtt megjelent egy magyar nyelvú könyvecske e témában (Zsolnai, 1989); az idén egy vaskos ökológiai közgazdaságtan szöveggyüjtemény látott napvilágot (Pataki -

\footnotetext{
* Szerkesztőségünkhöz lapzártakor érkezett meg Hammer Ferenc vitacikkének javított változata a szerzôtől, a jelen összeállításban ezt közöljük. Takács-Sánta András reflexiója a kézirat előző változatának ismeretében készült. - Lektor.
} 
Takács-Sánta, 2004), benne jó néhány konstruktív írással (pl. Kemp et al., 1998); de olvashatunk magyarul az alternatív kapitalistákról is (Pataki - Radácsi, 2000); sőt mi több, radikálisabb, a gazdasági lokalizációt favorizáló megoldásokról szintúgy (Dauncey, 1996). Az ökopolitikában talán a „lehet más a demokrácia!” a legelterjedtebb jelszó (pl. Aldred - Jacobs, 2000). Az életmód-alternatívákról a kitűnô (bár ma már sajnos nehezen hozzáférhetô) Zöldköznapi Kalauzban olvashatunk (Könczey - S. Nagy, 1996). És a sor még folytatható volna. Kéretik tehát tájékozódni, olvasni, és ha egy mód van rá, mindörökre elfelejteni az unalmas, elavult, igaztalan közhelyet, miszerint „a zöldek csak 'nem'-et tudnak mondani”.

És ezt ajánlanám zárásképpen - méghozzá jó szívvel - Sükösd Miklós kritikusainak: érdemes volna minél nagyobb tájékozottságra szert tenniük az ökológiai problémák és lehetséges megoldásaik témakörében. Ehhez véleményem szerint jó kiindulópontul szolgálhat jelen írás hivatkozásjegyzéke, amit még néhány további olvasmányajánlattal is kiegészítek. Továbbá - már csak azért is, hogy mondjak néhány példát arra, mire is lehet jó az (internetes) média, merthogy a vita többi résztvevôjéhez hasonlóan én sem vagyok esküdt ellensége annak - mindenki figyelmébe ajánlom a Védegylet által múködtetett könyv- és folyóirat-ajánló levelezólistát (zoldirodalom@zpok.hu), mintegy 70 db magyar nyelvű „zöld” könyv ajánlóját a Védegylet honlapján (www.vedegylet.hu), valamint legfóképpen az egyik legszínvonalasabb magyar nyelvư honlapot, a naponta frissülố www.greenfo.hu környezetvédelmi hírportált.

A tájékozódást nemcsak azért merem ajánlani Miklós kritikusainak, mert mindenkinek érdemes jól informáltnak lennie a civilizációnkat jelenleg fenyegetô legnagyobb veszélyrôl. (Merthogy Z Karvalics László záró dilemmájára egyértelmûnek látszik a válasz: az ökokalipszisre ma sokkal nagyobb esély mutatkozik, mint egy kozmikus katasztrófára.) És nem is csak azért, mert ezáltal (még) színvonalasabbak lennének az ilyesfajta viták. Hanem azért is - és talán ez a legfontosabb -, mert ennek következtében alighanem számos tévhitüktől megszabadulnának, s így jelentôsen csökkennének a köztünk levô nézetkülönbségek. Tudom, hogy ez roppant nehéz dolog, hiszen a hiedelmek mögött gyakran igencsak makacs, a változásra nemigen hajlamos értékek állnak. Ugyanakkor bízom abban, hogy jelen írás is hozzájárult valamicskét egyes életveszélyes mémek gyakoriságának csökkenéséhez. 
IRODALOM

Aldred, J. - M. Jacobs (2000): Citizens and wetlands: evaluating the Ely citizen's jury. Ecological Economics, 34 (2000): 217-232. (Magyarul: Állampolgárok és vizes élóhelyek: az Ely-i állampolgári tanács értékelése. In: Pataki - Takács-Sánta 2004.)

Arrow, K. et al. (1995): Economic Growth, Carrying Capacity, and the Environment. Science, 1995, 268: 520-521. (Magyarul: Gazdasági növekedés, eltartóképesség és környezet. In: Pataki - Takács-Sánta 2004.)

Daily, G. (ed.) (1997): Nature's Services: Societal Dependence on Natural Ecosystems. New York: Island Press.

Dauncey, G. (1996): After the Crash: The Emergence of a Rainbow Ecomomy, New Edition. London: Merlin Press. (Magyarul: Összeomlás után - A szivárványgazdaság kialakulása. Budapest, Göncöl Kiadó, 2001.)

de Groot, R. S. et al. (2002): A typology for the classification, description and valuation of ecosystem functions, goods and services. Ecological Economics 41, 393-408.

Diamond, J. M. (1989): The present, past and future of human-caused extinctions. Philosophical Transactions of the Royal Society of London, Series B 325, 469-477.

Durning, A. (1991): Mennyi az elég? In: A világ helyzete 1991, 156-171.o. Budapest: Föld Napja Alapítvány.

Ehrlich, P. R. - A. H. Ehrlich (1981): Extinction. New York: Random House. (Magyarul: A fajok kihalása. Budapest: Göncöl Kiadó, 1995.)

Gonczlik A. (2004): Azélővilág adományaiés veszélyeztetettségük. (Kiadatlan szakdolgozat. Elérhetô

http://www.greenfo.hu/adatbazisok/szakdolgozatok_item.php?sz $\mathrm{d}=9$ címen.)

Imreh I. (1993): A természeti környezet oltalmazása a székely rendtartásokban. In: R. Várkonyi Á. és Kósa L. (szerk.): Európa híres kertje: Történeti ökológia tanulmányok Magyarországról, 122-140.o. Budapest: Orpheusz Könyvkiadó.

Johannes, R. E. (1978): Traditional marine conservation methods in Oceania and their demise. Annual Review of Ecology and Systematics 9, 349364. (Magyarul: Hagyományos tengeri természetvédelmi módszerek és hanyatlásuk Óceániában In: Pataki \& TakácsSánta 2004.)

Juhász-Nagy P. (1979): A környezetvédelem ökológiai alapjai. MTA Biológiai Osztályának Közleményei 22, 297-309.

Kemp, R. et al. (1998): Regime shifts to sustainability through processes of niche formation: The approach of strategic niche management. Technology Analysis \& Strategic Management 10(2), 175-195. (Magyarul: Technológiai rezsimváltások a fenntarthatóság irányába nicheképződések folyamatain keresztül: a stratégiai niche-menedzsment megközelítése. In: Pataki - Takács-Sánta 2004.) 
Könczey R. - S. Nagy A. (1996): Zöldköznapi kalauz (2. kiadás). Budapest: Föld Napja Alapítvány.

Kunin, W. E. - J. H. Lawton (1996): Does biodiversity matter? Evaluating the case for conserving species. In: K. J. Gaston (ed.): Biodiversity: A Biology of Numbers and Difference, pp. 283-308. Oxford: Blackwell Science.

Meyer, W. (1996): Human Impact on the Earth. Cambridge: Cambridge University Press.

Pataki Gy. - Radácsi L. (2000): Alternativ kapitalisták. Szentendre: Új Paradigma.

Pataki Gy. - Takács-Sánta A. (szerk.) (2004): Természet és gazdaság - Ökológiai közgazdaságtan szöveggyújtemény. Budapest: Typotex Kiadó.

Pálfy J. (1999): Kihaltak és túlélők - Félmilliárd éo nagy fajpusstulásai. Budapest: Vince Kiadó.

Pimm, S. L. et al. (1995): The future of biodiversity. Science 269, pp. 347-350.

Sawin, J. (2003): Az enegiaellátás jövőképe. In: A világ helyzete 2003, pp. 119-149. Budapest: Föld Napja Alapítvány.

Smil, V. (2002): The Earth's Biosphere. Cambridge: MIT Press.

Smil, V. (2003): Energy at the Crossroads. Cambridge: MIT Press.

Takács-Sánta A. (1999): A nélkülözhetetlen sokféleség - 1. rész: A biodiverzitás Cédrus II/10, 3-5. (A http://www.tabulas.hu/ cedrus/1999/ 10/merito.html\# teteje címen is elérhetô.)

Vida G. (2001): Helyünk a bioszférában. Budapest: Typotex Kiadó.

Wackernagel, M. - W. E. Rees (1996): Our Ecological Footprint. (Magyarul: Ökológiai lábnyomunk. Budapest: Föld Napja Alapítvány, 2001.)

Watson, R. T. et al. (eds.) (2001): Intergovernmental Panel on Climate Change Third Assessment Report - Climate Change 2001: Synthesis Report. Cambridge: Cambridge University Press. (A teljes szöveg elérhető a www.ipcc.ch címen is.)

Zsolnai L. (1989): Másként gazdálkodás. Budapest: Közgazdasági és Jogi Könyvkiadó.

Ajánlott olvasmányok:

Gadó Gy. P. (szerk.) (2000): A természet romlása, a romlás természete Budapest: Föld Napja Alapítvány. (Magyarország helyzete.)

Homer-Dixon, T. (2004): Környezet, szúkösség, erốszak. Budapest: Typotex Kiadó. (Kitûnő összefoglaló munka a természeti erőforrások szúkösségére visszavezethető fegyveres konfliktusokról a téma legjobb szakértôjétôl.)

Lányi A. (szerk.) (2000): Természet és szabadság - Humánökológiai olvasókönyv. Budapest: Osiris Kiadó. (Klasszikus és újabb humánökológiai írások, köztük számos remekmû.)

McDaniel, C. - J. Gowdy (2002): Az édenkert kiárusitása - Példázat a természet tönkretételéról. Budapest: Typotex Kiadó. (Remek, olvasmányos könyv egy biológus és egy közgazdász szerző együttmúködéséből.)

Schumacher, E. F. (1991): A kicsi szép. Budapest: Közgazdasági és Jogi Könyvkiadó. (Az alternatív közgazdaságtan klasszikusa.)

Standovár T. - R. B. Primack (2001): A természetvédelmi biológia alapjai. Budapest: Nemzeti Tankönyvkiadó. (Remek, részletes tankönyv.) 
Vay M. (szerk.) (2004): Meddig vagyunk? - Válogatott írások a Védegylettól. Budapest: noran.

Cohen, J. E. (1995): How Many People Can the Earth Support? New York: Norton. (Alighanem a legjobb könyv a népesedési problémáról.)

Laurance, W. F. (1999): Reflections on the tropical deforestation crisis. Biological Conservation 91, pp. 109-117. (Kiváló összefoglaló cikk a trópusi erdőirtásokról.)

McNeill, J. R. (2000): Something New Under the Sun: An Environmental History of the Twentieth Century. New York: Norton. (Kitûnő könyv a XX. század történelméról az emberi környezetátalakítás szempontjából.)

Takács-Sánta A. (2004): The major transitions in the history of human transformation of the biosphere. Human Ecology Review 11(1), pp. 51-66. (A cikk teljes szövege elérhetô www.humanecologyreview. org/111.htm címen is.)

Turner, B. L. II. et al. (eds.) (1990): The Earth as Transformed by Human Action: Global and Regional Changes in the Biosphere over the Past 300 Years. Cambridge: Cambridge University Press. (Sokszerzős, vaskos kompendium, a legátfogóbb mû az ember természetátalakító tevékenységéről.) 